S. Afr. J. Agric. Ext.

Vol. 44, No. 2, 2016: $231-247$

Davis \&

DOI: http://dx.doi.org/10.17159/2413-3221/2016/v44n2a428

Terblanché.

\title{
CHALLENGES FACING THE AGRICULTURAL EXTENSION LANDSCAPE IN SOUTH AFRICA, QUO VADIS?
}

Davis, K. E. ${ }^{51} \&$ Terblanché, S. E. ${ }^{52}$

\section{ABSTRACT}

According to the National Development Plan for South Africa there is a need for the training of a new cadre of agricultural extension advisors that will respond effectively to the needs of small-holder farmers. What is needed is a "best-fit" framework for designing and analysing agricultural advisory services namely: Policy environment; Governance (pluralism and participation); Capacity/competencies, technical and functional and the professionalising of the extension services (the South Africa case study). The role of the South African Society for Agricultural Extension (SASAE) in the way forward will be to: Determine continuously what the agricultural extension landscape will need in 10 years' time; establish and implement a Continuous Professional Development (CPD) Committee to ensure continuing professional development of extension advisors; and investigate the possibility to register as a training provider of skills programs in the science of extension.

Keywords: Extension landscape; professionalism; competencies; pluralism

\section{INTRODUCTION}

According to the National Development Plan for South Africa and its Vision for 2030, South African's rural communities should have greater opportunities to participate fully in the economic, social and political life of the country. Rural economies will be supported by agriculture and possibly by mining, tourism, agri.-processing and fisheries (see Chapter 6: An integrated and inclusive rural economy). The following aspects were identified as essential, with special reference to extension and advisory services in South Africa:

- "Improve and extend skills development and training in the agricultural sector, including entrepreneurship training and the training of a new cadre of extension officers that will respond effectively to the needs of small-holding farmers and contribute to their successful integration into the food value chain.

- For these extension officers to be successful, it is necessary to investigate whether extension and other agricultural services are appropriately located at provincial level. Innovative means for agricultural extension and training by the state in partnership with industries should be sought" (National Planning Commission, 2012: 206).

This is a clear indication that an effective and efficient extension and advisory service is essential for successful rural development in South Africa. This document examines ingredients for effective, efficient advisory services, based on an international and local literature review. The purpose of the study is to identify challenges facing the agricultural extension landscape from a global perspective namely a best-fit approach and a framework for designing and analysing agricultural and rural advisory services that include:

- Policy environment

- Governance

\footnotetext{
${ }^{51}$ Global Forum for Rural Advisory Services/International Food Policy Research Institute, South Africa. Email: kristin.davis@g-fras.org.

${ }^{52}$ University of Pretoria, South Africa Email: fanie.terblanche@up.ac.za.
} 
S. Afr. J. Agric. Ext.

Vol. 44, No. 2, 2016: $231-247$

DOI: http://dx.doi.org/10.17159/2413-3221/2016/v44n2a428

- Capacity, management and organisation

- Approaches
Davis \&

Terblanché.

(Copyright)

\section{CHALLENGES FACING THE AGRICULTURAL EXTENSION ADVISORY LANDSCAPE - A GLOBAL PERSPECTIVE}

A desktop study of international extension and advisory research between 2001 and 2015 revealed a number of challenges facing the agricultural extension advisory landscape. The challenges are organised according to the 'best-fit' framework (Birner, Davis, Pender, Nkonya, Anandajayasekeram, Ekboir, Mbabu, Spielman, Horna, \& Benin, 2009). This thinking is echoed by Rivera \& Qamar (2003), who stated that "no two people are exactly alike"; it is important to realise that no single extension methodology is suitable for all situations and for all purposes. A 'one-size-fits-all' approach to sustainable extension and rural development programmes will not work. The need to develop location-specific extension approaches is essential and in line with developing situation specific food security strategies. The best-fit approach embraces both the pluralism of approaches used today and the diversity found within agricultural innovation systems (GFRAS, 2012). The framework for designing and analysing agricultural advisory services looks at the impact pathways and influencing factors for successful performance and impact of extension services. It starts with the contextual factors or 'frame conditions', including the policy environment (A), the general capacity of service providers (B), and the production/farming systems and community aspects $(C \& D)$. The framework then looks at the characteristics of the advisory service system that must respond to the frame conditions. These characteristics include governance structures $(\mathrm{E})$, capacity $(\mathrm{F})$, management $(\mathrm{G})$, and extension techniques or methods used $(\mathrm{H})$. The conditions and characteristics then affect the performance of the service (I), the response through capacity building and decision making of farm households (J) and leads to impact (K). 
S. Afr. J. Agric. Ext.

Vol. 44, No. 2, 2016: 231 -247

DOI: http://dx.doi.org/10.17159/2413-3221/2016/v44n2a428
Davis \&

Terblanché.

(Copyright)

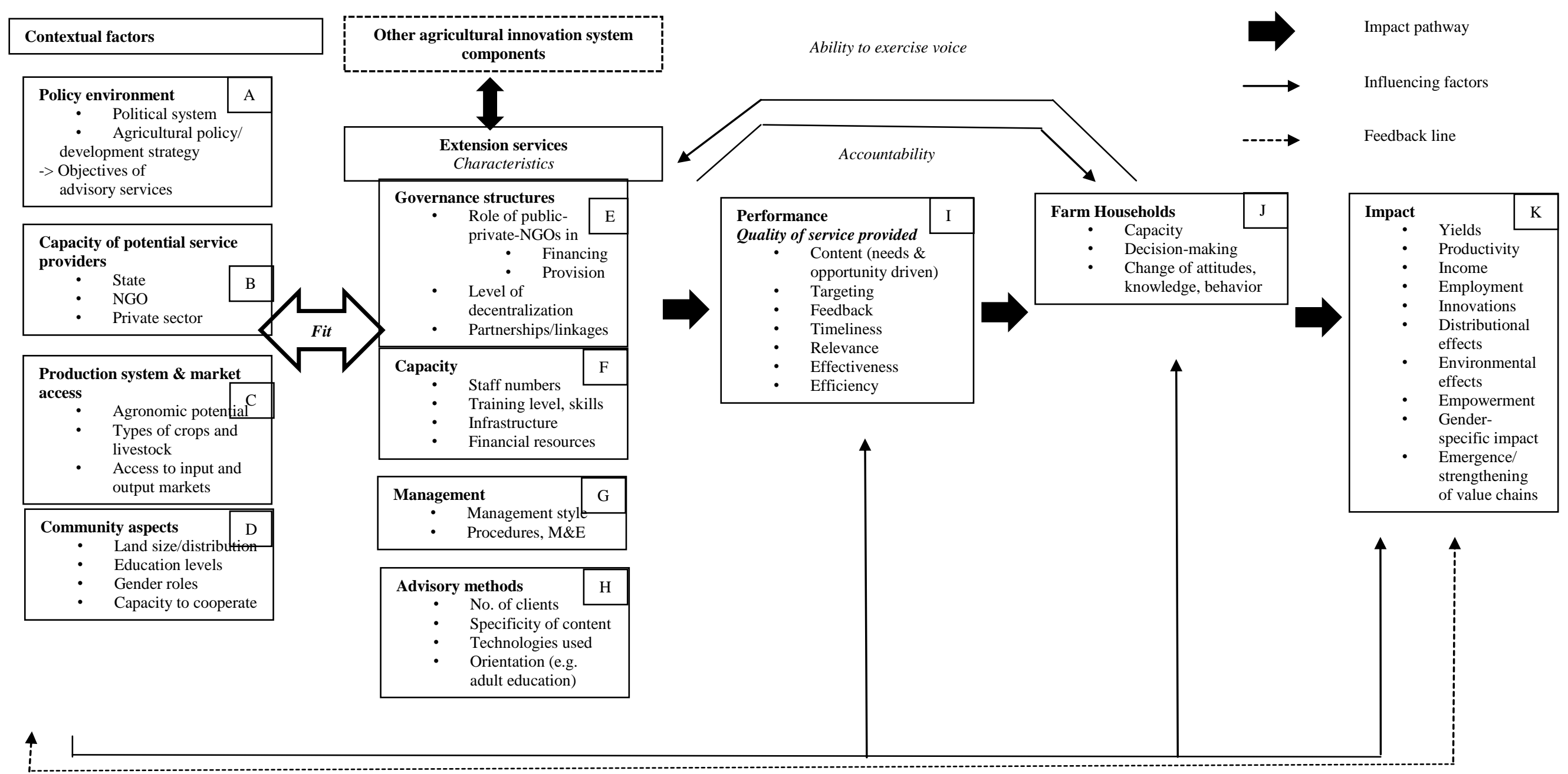

Figure 1: Framework for analysing advisory services (Biner, et al., 2009) 
S. Afr. J. Agric. Ext.

Vol. 44, No. 2, 2016: $231-247$

DOI: http://dx.doi.org/10.17159/2413-3221/2016/v44n2a428
Davis \&

Terblanché.

(Copyright)

The study now look at the extension characteristics affecting performance of advisory services, and thus impact. The study also examines in turn policy, governance, and capacity and management.

\subsection{Policy Environment}

Revitalising extension and advisory services was the focus of a landmark conference held in Nairobi in November 2011 (Pye-Smith, 2012), resulting in the Nairobi Declaration. One of the root causes of low productivity in Africa is the poor performance of the extension and advisory services, and the lack of financial support they receive (Pye-Smith, 2012: 5). It is therefore important to formulate national policies and strategies on extension and to ensure political and functional commitment (Qamar, 2005). Extension reform requires a policy vision and determination, as well as a nationwide strategy that can be effectively implemented (Rivera \& Qamar, 2003). Policies and strategies must depend on government priorities and the needs of clientele. However, in formulating extension policy, and thus the roles of extension services and extension agents, it is important to note that today, for better or for worse, extension agents do more than just 'traditional' extension and technical agricultural outreach. They play a much bigger role, brokering and facilitating links and relationships within the agricultural innovation system, and thus require new strategies and capacities to perform these roles (Sulaiman \& Davis, 2012). For policy-makers, extension is a much needed investment in human and social capital of the rural population of a nation. Specific attention must be given to:

- Prospects for regional and global platforms such as the African Forum for Agricultural Advisory Services (and their country forums) and the Global Forum for Rural Advisory Services

- Poverty alleviation, food security and risk reduction

- Gender equality in extension

- Rethinking priorities for pro-poor extension

- Market-orientation and demand drive

- Extension in research for development (Christoplos, 2010).

In an updated review of African extension policy, Idowu (2015) shows that from a list of 27 countries under review in, 13 countries have a legislated extension policy. The analysis showed that there is need to create awareness about the linkage that should exist between extension policy and Comprehensive Africa Agriculture Development Program (CAADP) pillars.

In the Republic of South Africa (RSA) the National Extension and Advisory Service Policy (DAFF, 2014) has been developed, but is still in draft format and awaiting final approval. The policy aims to set a regulatory framework to guide the agriculture, forestry and fisheries sectors in the provision of extension and advisory services. The new policy will require a multidisciplinary approach for the capacity development of extension professionals with the relevant and diverse knowledge and tools. Thus policy-makers, extension managers, and training institutions must:

- Review and develop multidisciplinary training curricula for extension practitioners;

- Ensure continuous professional development through systematic maintenance, improvement and broadening of knowledge and skills; and 
- Review academic curricula to develop well-trained extension professionals and contribute to the knowledge support system of government, offering accredited inservice training to extension practitioners.

One danger in developing extension policies is that they remain only on paper and are not implemented due to political change, lack of political will or lack of resources and capacity to do so. Part of the process of policy development is the development of an implementation framework and a monitoring and evaluation system to track and judge the policy's performance and impact.

\subsection{Governance}

Rivera, Qamar, and Van Crowder (FAO, 2001) looked at options for institutional reform of extension in developing countries. The focus was on reform measures that promote food security and poverty alleviation among smallholder farmers. The reform initiatives were:

a) Pluralism in advisory service provision

Pluralism of extension providers, involving coordinated partnerships with non-profit non-governmental organisations. Pluralism is much touted amongst development practitioners. Pye-Smith (2012: 11) stated that "there is a very strong argument in favour of creating a pluralistic system of delivery, which is participatory and demandled". Pluralism can be promoted in extension by involving public, private, and civil society institutions (Qamar, 2005). Pluralism in advisory services provides the opportunity to capitalise on the comparative advantages of different types of providers. However, coordination of such providers is challenging, particularly in ensuring that vulnerable sectors of the farming population have access to services and avoiding duplication of efforts (Christoplos, 2010: 6). The effective role of the private sector must be considered. In the future, more agricultural technology will be developed and sold by private-sector companies - thus the process of technology transfer will be increasingly privatised and handled by private firms. In developing countries the forming of public-private partnerships will reduce the need for so many government front-line public extension agents (Swanson, 2008). A pluralistic extension pattern demands that programmes/projects be jointly planned, implemented and evaluated by all service providers, in active collaboration with farmers (Rivera \& Qamar, 2003). For pluralism to work, extension implementers, especially national extension services, must ensure effective operational linkages between extension and research and other key relevant institutions (Qamar, 2005).

b) Participation and ensuring accountability to local clients (decentralisation to lower tiers of government).

There are increasing calls for 'demand-driven' and 'farmer-led' rural advisory services using participatory approaches (GFRAS, 2012). When promoting participation and accountability, it is important to think critically about who participates and who is accountable to whom. Policy-makers, planners and field-level programme staff can encourage bottom-up, grassroots extension programme planning by farmers to make extension demand-driven, but also exercise supply-driven, topdown modalities for promoting common public goods such as natural resource management or vaccination services (Qamar, 2005). 
S. Afr. J. Agric. Ext.

Vol. 44, No. 2, 2016: $231-247$

DOI: http://dx.doi.org/10.17159/2413-3221/2016/v44n2a428
Davis \&

Terblanché.

(Copyright)

Decentralisation is taking place in more and more countries. Four types of administrative decentralisation include de-concentration, delegation, devolution and transfer to non-government institutions. Decentralisation, if well planned, can also increase accountability to rural people through subsidiarity - placing responsibility for activities at the frontline where extension services are closer to farmers (GFRAS, 2012). Accountability to rural people also means knowing whether a programme or organisational innovation actually worked or not and taking action to respond to challenges (GFRAS, 2012: 7).

Stakeholder participation in decision-making processes is crucial and requires collaboration, partnerships and coordination (Rivera \& Qamar, 2003).

At the Nairobi conference, participants found that "...with greater coordination of extension, it will be easier to build synergies with research and education to provide the relevant knowledge base for transforming agriculture" (Pye-Smith, 2012: 9).

\subsection{Capacity, Management and Organisation}

Capacity, management and advisory service organisation are critical components of an effective extension system. But this very much depends upon the role extension is expected to play. According to Christoplos (2010), these roles include:

- Dissemination of information about technologies, new research, markets, input and financial services, and climate and weather.

- Training and advice to individual farmers, groups of farmers, famer organisations, cooperatives and other agri-business along the market chain.

- Testing and practical adaptation of new technologies and practices on-farm.

- Development of business management skills among smallholder farmers and other local entrepreneurs.

- Facilitation of linkages among market actors.

- Linking smallholder farmers, rural entrepreneurs and other members of the agricultural community with institutions offering training and education in fields relevant to the agricultural sector.

- Facilitation of linkages between farmers, their organisations and the public sector.

- Increasing awareness of new opportunities for certification of 'green', fair trade and other production methods.

- Facilitating access to non-extension government support.

"In the past, when people talked about capacity development, they were largely referring to providing technical knowledge and information to farmers. Nowadays, the focus has begun to change, and at the conference we looked more broadly at capacity building using an "innovation systems perspective"" (Pye-Smith, 2012: 20). This assumes that the extension agents of the future - or the "new extension professionals" - will have a responsibility that goes beyond providing farmers with technical information. They will also require 'soft' or functional skills that enable them to generate and promote innovations; improve the management of farmer organisations and agribusinesses, and build alliances and networks of different groups and individuals along the value chain (Pye-Smith, 2012: 20). Human resources are a fundamental bottleneck to effective extension services, given the challenges facing rural development. Human resource development does not include just basic or preservice education, but also continuing education, in-service and on-the-job training. Looking 
S. Afr. J. Agric. Ext.

Vol. 44, No. 2, 2016: $231-247$

Davis \&

DOI: http://dx.doi.org/10.17159/2413-3221/2016/v44n2a428

Terblanché.

(Copyright)

at the levels of capacity development, the new extensionist position paper (Sulaiman \& Davis 2012: 8-9) summarises the following from the Nairobi conference:

a) Individual. Effective advice is no longer a matter of simply providing messages about set technological packages but must include functional capacity to manage organisational and social processes.

b) Organisational. Extension organisations need to be capable of managing innovation, coordination, alliance building, mediation, management and facilitation to deal with the complex agricultural challenges we face today.

c) System. The overall agricultural knowledge and information system needs to change if extension is to operate effectively.

d) Capacities to manage change. Resilience and risk management are critical competencies that must be developed at all levels (individual, organisational and system).

While capacity should focus at individual, organisational and system level (Sulaiman \& Davis, 2012), human capital development is an essential ingredient of extension services as extension agents are the 'front line' of extension services (Rivera \& Qamar, 2003). Both Romero (2012) and Sulaiman \& Davis (2012) see rural extension as part of an innovation system. In their model of extension services embedded in an agricultural innovation system, Sulaiman \& Davis (2012) lay out three levels at which capacity is needed in extension (individual, organisational and system). The capacities needed at individual level, from a global perspective, are listed in Table 1.

Table 1: Capacities required at the individual level globally

\begin{tabular}{|l|l|}
\hline Technical & Functional \\
\hline Good understanding about appropriate/relevant/new & Community mobilisation \\
technologies/practices/standards/ & Farmer organisational development \\
regulations/policies in agriculture and natural resource & Facilitation \\
management including: & Coaching \\
Technical options to support climate change & Reflective learning \\
Adaptation & Mediating conflict \\
Agri-business & Negotiating \\
Value chain development & Brokering \\
Improving resource use & Networking and partnership development \\
Efficiency; application of biotechnology & Leadership capacity \\
Intellectual property and farmer rights & Managing resources \\
Use of new information \& ICTs & Critical thinking \\
& Problem-solving \\
& Self-reflection - learning from mistakes \\
& Service mindedness \\
& Accountability \\
& Responsibility \\
& Dedication/commitment \\
& Working in teams \\
\end{tabular}

Source: Sulaiman and Davis ( 2012)

To undertake these new duties and responsibilities outlined in Table 1, most extension staff members, especially those with diploma-level training, will need intensive in-service training and education (Swanson, 2008). The GFRAS Consortium on Extension Education and Training has taken up the New Extensionist concept outlined in Sulaiman \& Davis (2012) to promote reform of extension education services. They call for the competencies indicated in Table 1 to be integrated into training curricula for extension agents (Davis, 2015). 
S. Afr. J. Agric. Ext.

Vol. 44, No. 2, 2016: $231-247$

DOI: http://dx.doi.org/10.17159/2413-3221/2016/v44n2a428
Davis \&

Terblanché.

(Copyright)

The New Extensionist document calls for countries and regions to:

- Establish and strengthen training centres; contract in specific competencies required for supporting capacity development.

- Develop curricula for vocational and continuing education and skill up-gradation of individuals in extension and advisory services and undertake curriculum revisions at least once every five years (Sulaiman \& Davis, 2012).

The GFRAS Consortium has further put together a set of "core competencies" (Table 2) that are required for extension agents around the globe to function effectively (Davis, 2015). 
S. Afr. J. Agric. Ext.

Vol. 44, No. 2, 2016: $231-247$

DOI: http://dx.doi.org/10.17159/2413-3221/2016/v44n2a428
Davis \&

Terblanché.

(Copyright)

Table 2: Core Competencies for Extension and Advisory Services

\begin{tabular}{|c|c|}
\hline Area & $\begin{array}{l}\text { Competencies Required: Extension Professional Should be Able } \\
\text { to... }\end{array}$ \\
\hline Introduction to the new extensionist & $\begin{array}{l}\text { Define the framework of agricultural innovation systems and position } \\
\text { himself or herself within the innovation system } \\
\text { Define his or her new roles and new capacities that are required for } \\
\text { the new extensionist }\end{array}$ \\
\hline $\begin{array}{l}\text { Changing role of extension in } \\
\text { innovation and development }\end{array}$ & $\begin{array}{l}\text { Explain the role of extension in innovation and development } \\
\text { Give an overview of approaches and tools } \\
\text { Select appropriate approaches and tools for a given context }\end{array}$ \\
\hline Extension programme management & $\begin{array}{l}\text { Conduct extension programme planning, implementation, monitoring, } \\
\text { and evaluation } \\
\text { Use different types of problem solving techniques } \\
\text { Build strategic partnerships, network, and manage stakeholders } \\
\text { Pluralism in extension and the need for and methods of coordination } \\
\text { and linkages }\end{array}$ \\
\hline Professional ethics & $\begin{array}{l}\text { Apply values and good principles such as honesty, respect, } \\
\text { accountability inclusion, transparency, integrity } \\
\text { Recognise extension as a science and extension as a profession }\end{array}$ \\
\hline Adult learning and behaviour change & $\begin{array}{l}\text { Practice adult learning design and implement adult learning } \\
\text { programmes } \\
\text { Initiate and support social networks for agricultural innovation }\end{array}$ \\
\hline Communication for innovation & $\begin{array}{l}\text { Communicate with all stakeholders in the agricultural innovation } \\
\text { system } \\
\text { Manage knowledge effectively } \\
\text { Identify and use appropriate ICTs } \\
\text { Identify cultural and gender implications in communication and } \\
\text { innovation }\end{array}$ \\
\hline Facilitation for development & $\begin{array}{l}\text { Vision and organise demands } \\
\text { Build local organisational capacities } \\
\text { Broker and build linkages with actors in the innovation system }\end{array}$ \\
\hline Community mobilisation & $\begin{array}{l}\text { Conduct livelihoods assets assessment } \\
\text { Use problem solving and decision making approaches } \\
\text { Explain leadership principles and leadership development } \\
\text { Explain implications of culture and diversity, including gender and } \\
\text { youth } \\
\text { Mobilise resources }\end{array}$ \\
\hline Farmer institutional development & $\begin{array}{l}\text { Explain or define theory, models, and types of groups and } \\
\text { organisations } \\
\text { Manage group dynamics } \\
\text { Explain how the policy environment and "rules of the game" } \\
\text { influence organisations }\end{array}$ \\
\hline Value chain extension & $\begin{array}{l}\text { Explain basic concepts and tools for value chain approaches } \\
\text { Link farmers to market (input and output markets) } \\
\text { Analyse consumer preferences } \\
\text { Respond to standards certification and regulatory systems }\end{array}$ \\
\hline Agricultural entrepreneurship & $\begin{array}{l}\text { Analyse business opportunities and conduct market analysis } \\
\text { Promote farm entrepreneurship }\end{array}$ \\
\hline $\begin{array}{l}\text { Gender and youth issues in agricultural } \\
\text { extension and rural development }\end{array}$ & $\begin{array}{l}\text { Appreciate gender differences through the following questions: who } \\
\text { does what, with what, how and why? } \\
\text { Use gender-sensitive approaches } \\
\text { Engage and retain rural youth }\end{array}$ \\
\hline Adaptation to change & $\begin{array}{l}\text { Enhance adaptive capacities of communities to different types of risks } \\
\text { and uncertainties related to climate change, markets and disasters } \\
\text { Analyse tools for adaptation options } \\
\text { Deal with risks, change, and uncertainties }\end{array}$ \\
\hline
\end{tabular}

Source: Davis (2015) 
Extension agents cannot be expected to be experts in every technical and functional field. However, they should know how to broker information needed by their clientele. They also must be backed up by subject matter specialists. Other areas where extension agents may be called upon to work, depending on the local context, include:

- Food and nutrition security-related global developments that could eventually effect rural livelihoods (Qamar, 2005; Fanzo, Marshall, Dobermann, Wong, Merchan, Jaber, Souza, Verjee, \& Davis, 2015).

- Forming and strengthening farmer groups (social capital) to gain economies of scale and to more efficiently supply markets (Swanson, 2008).

- Sustainable natural resource management, including water use management, soil and land use management and integrated pest management (Swanson, 2008).

- Climate change and other areas of risk.

- Linking and brokering relationships between scientific research, field-level innovations and innovators, markets, education and other services (GFRAS, 2012: 2).

- Promoting food production increase and reducing food losses to ensure food availability at reasonable prices (Christoplos, 2010).

- Encouraging the creation of more livelihood opportunities to reduce risk and earn income (Christoplos, 2010).

Finally, the issue of professionalism is a critical one. We need to give the extension profession a long overdue status similar to other agricultural disciplines (Qamar, 2005; Davis, 2015). This issue is covered in the following sections.

\section{i. Capacity Needs in South Africa}

A report on the profiles of government extension and advisory service officers (Directorate Education and Training, 2007) noted that about $80 \%$ of extension officers had a qualification of a diploma or lower. However, norms and standards requires a degree or higher. Technical skills of most extension officers in RSA include animal production, crop production, horticulture, business management, LandCare and mechanisation and irrigation (Directorate Education and Training, 2007). The report ended by recommending that the Directorate Education, Training and Extension Services should facilitate training in soft skills, possibly through a Frontline Extension Officers Development Programme and Extension Officers Management Development Programme. Similarly, the Agricultural Education and Training Strategy 2005 noted that there was a need for more practical skills in agriculture and improvement in marketing, farm and environmental management and value adding (Directorate Education and Training, 2005). At the time of publication the National Agricultural Education and Training Forum was launched, but disbanded around 2008.

In 2005 the Standard Generating Body (SGB) for Agricultural Extension, through a process of consultation and workshops, developed an Agricultural Extension Landscape. Terblanché (2008) discusses the outcomes. The landscape indicated specific extension concepts, study fields and essential skills and knowledge areas that every extension worker needs to successfully fulfil his/her task in a professional manner (Table 3). 
S. Afr. J. Agric. Ext.

Vol. 44, No. 2, 2016: $231-247$

DOI: http://dx.doi.org/10.17159/2413-3221/2016/v44n2a428
Davis \&

Terblanché.

(Copyright)

Table 3: The Agricultural Extension Landscape in South Africa - Extension Concepts

\begin{tabular}{|l|l|}
\hline EXTENSION CONCEPT & STUDY FIELD \\
\hline $\begin{array}{l}\text { Communication and interaction } \\
\text { (The vehicle through which extension } \\
\text { takes place) }\end{array}$ & $\begin{array}{l}\text { Communication } \\
\text { Group facilitation }\end{array}$ \\
\hline $\begin{array}{l}\text { Extension methodology } \\
\text { (implementation and managing } \\
\text { the extension process) }\end{array}$ & $\begin{array}{l}\text { Approaches to extension } \\
\text { Management in extension }\end{array}$ \\
\hline $\begin{array}{l}\text { Extension philosophy and practice } \\
\text { (the science of extension) }\end{array}$ & $\begin{array}{l}\text { Behaviour change } \\
\text { Decision-making }\end{array}$ \\
\hline $\begin{array}{l}\text { Contextual Extension } \\
\text { (the context or environment of extension } \\
\text { Practicing) }\end{array}$ & $\begin{array}{l}\text { Community development } \\
\text { Extension policymaking }\end{array}$ \\
\hline
\end{tabular}

\section{ii. Professionalising Extension Services}

Along with qualifications come norms and standards. The Norms and Standards for Agricultural Extension and Advisory Services in South Africa (2005: 7 - 10) document was a culmination of protracted discussions within the sector on the current status of extension services in RSA, and a need to improve the system. The document covers the competencies and skills required in extension's human resources:

A person employed as an agricultural extension advisor at all levels shall be required to have a minimum qualification of a bachelor's degree as well as a higher degree in extension and must register with the recognised relevant professional body.

Extension and advisory services in RSA therefore need a cadre of well-trained, dedicated and motivated staff skilled in agricultural production as well as functional extension and communication techniques. The provision of effective and on-going training is therefore in the long-term interest of the agricultural and advisory services. The training needs of extension officers must be continuously assessed and in-service training implemented accordingly.

The shortage of trained and experienced agricultural extensionists in South Africa has been the subject of much debate in recent years. The Department of Agriculture, Forestry and Fisheries (DAFF) has taken active steps to address the shortage of extensionists in the country through the development and roll-out of its Agricultural Extension Recovery Plan in all nine provinces. DAFF proposed that agricultural extension be formally recognised as a profession, governed by a legal framework and require formal registration and continuous professional development. DAFF requested the South African Society for Agricultural Extension (SASAE) to undertake a study on the feasibility of establishing a professional body for the registration of agricultural extensionists and advisors (Terblanché \& Koch, 2012).

The study focused on the pros and cons of establishing a new professional council under the auspices of DAFF or pursuing registration under the South African Council for Natural Scientific Professions (SACNASP) and to determine the levels for professional registration. 
S. Afr. J. Agric. Ext.

Vol. 44, No. 2, 2016: $231-247$

DOI: http://dx.doi.org/10.17159/2413-3221/2016/v44n2a428
Davis \&

Terblanché.

(Copyright)

According to Terblanché and Koch (2012) the purpose of the Natural Scientific Professions Act no 27 of 2003 was the establishment of the SACNASP and the registration of professional, candidate and certificated natural scientists.

According to Schedule 1 of the Act, no one may practice in any of the 21 listed fields of practice unless he/she is registered in a category of the schedule. The latest fields of practice published under Notice 36 of 2014 by the Minister of Science and Technology includes Extension Science as a field of practice. As to legality: only registered persons may practice in a consulting, extension/advisory capacity. The study suggested that agricultural and forestry consultants/advisors/extensionists can register under one or more of the following fields of practice:

- Agricultural Science;

- Animal Science;

- Soil Science; and/or

- Extension Science.

There are certain requirements for registration. For a Natural Scientist, it includes the following:

- The Professional Natural Scientist (Pr. Sci. Nat.) - 4yr BSc Agric degree or similar higher +3 yrs experience.

- A Candidate Natural Scientist (Cand. Sci. Nat.) - 4yr BSc Agric degree or similar higher + zero experience. 2 or $3 \mathrm{yr}$ degree or diploma or equivalent qualification and between one and five years' experience.

- A Certificated Natural Scientist (Cert. Sci. Nat.) 2 or 3 year degree or diploma or equivalent qualification and between one and five years' experience.(SACNASP, 2014)

Table 4 indicates the registration categories for extension professionals. 
S. Afr. J. Agric. Ext.

Vol. 44, No. 2, 2016: $231-247$

DOI: http://dx.doi.org/10.17159/2413-3221/2016/v44n2a428
Davis \&

Terblanché.

(Copyright)

Table 4: Extension Science Category Requirements for RSA

\begin{tabular}{|l|l|}
\hline Category and Designation & Requirements \\
\hline Professional Extension Scientist (Pr. Ext. Sci.) & $\begin{array}{l}\text { Post graduate qualification in } \\
\text { Extension; 120 extension credits on } \\
\text { Honours degree level; Masters/PhD } \\
\text { in Extension } \\
5 \text { years' work experience }\end{array}$ \\
\hline Candidate Extension Scientist (Cand. Ext. Sci.) & $\begin{array}{l}4 \text { year degree; 120 extension credits } \\
\text { on Honours level } \\
\text { Less than 5 years' work experience }\end{array}$ \\
\hline Extension Technologist Level A (Ext. Tech. A) & $\begin{array}{l}\text { Recognised extension qualification: } \\
60-119 \text { extension credits } \\
5 \text { years' work experience }\end{array}$ \\
\hline $\begin{array}{l}\text { Candidate Extension Technologist Level A } \\
\text { (Cand. Ext. Tech. A.) }\end{array}$ & $\begin{array}{l}\text { Recognised extension qualification: } \\
60-119 \text { extension credits } \\
\text { Less than 5 years' work experience }\end{array}$ \\
\hline Extension Technologist Level B (Ext. Tech. B) & $\begin{array}{l}\text { Recognised extension qualification: } \\
10-59 \text { extension credits } \\
5 \text { years' work experience }\end{array}$ \\
\hline $\begin{array}{l}\text { Candidate Extension Technologist Level B } \\
\text { (Cand. Ext. Tech. B) }\end{array}$ & $\begin{array}{l}\text { Recognised extension qualification: } \\
10-59 \text { extension credits } \\
\text { Less than 5 years' work experience }\end{array}$ \\
\hline $\begin{array}{l}\text { Associate Extension Technologist (Assoc. Ext. } \\
\text { Tech.) }\end{array}$ & $\begin{array}{l}\text { At least 10 years work, lacks } \\
\text { appropriate training } \\
2 \text { credible independent witnesses }\end{array}$ \\
\hline
\end{tabular}

Source: www.SACNSP.org.za

The Act also calls for continuous professional development (CPD). Under, this, persons registered as professionals are required by their Code of Conduct to practice strictly within their area of competence and to maintain and enhance this competence. They therefore have the responsibility to keep abreast of developments and knowledge in their areas of expertise in order to maintain their competence. In addition to maintaining their own competence, they should strive to contribute to the advancement of the body of knowledge with which they practice, and to the profession in general. A committee has to be established to develop CPD for Professional Extensionists and the roll out of the process.

In this process of professionalization of the extension service in South Africa the SASAE as a recognised and registered Voluntary Association by SACNASP will play an essential role in future.

The process of professional registration of extensionists with SACNASP was launched in the second half of 2014. At the end of March 2016 SACNASP received 2,778 applications from the nine provinces.

\subsection{Approaches}


S. Afr. J. Agric. Ext.

Vol. 44, No. 2, 2016: $231-247$

DOI: http://dx.doi.org/10.17159/2413-3221/2016/v44n2a428
Davis \&

Terblanché.

(Copyright)

The approaches (tools or methods) used to fulfil extension functions depend on many things: the number of clients, the specificity of content, the technologies and the orientation of the services (such as adult education) (Birner et al., 2009).

Participatory and farmer-driven approaches are used for needs based development and include community participation and involvement (Düvel, 2003). Extension services often work through farmer groups, organising them into legal associations to constitute a strong lobby for themselves and for extension (Qamar, 2005). Thus it is important for extension to build social capital and help organise producers groups (Swanson, 2008). Local NGOs can be used to organise subsistence farmers into self-help groups/producer organisations and link them to an extension agents. According to Swanson (2008), rural youth programmes should be implemented to enable rural young people to learn leadership and off-farm jobs.

While many people promote information and communication technologies (ICT's) to get information out to farmers and reduce costs, they are not a replacement for extension staff or institutions (Rivera \& Qamar, 2003). They are essential components of the development process and information technology tools and must facilitate the work of extension agents, as well as help to build their capacities.

\subsection{The role of SASAE as a Voluntary Association}

SACNASP registered SASAE with the support from DAFF to establish a CPD Committee to roll-out and implement the process of continuous development for extensionists in Extension as a Field of Practice and therefore as a Science. The Committee was established in December 2015 and are represented by the following stakeholders, SACNASP - three members, DAFF - three members and SASAE - four members. The Committee will specifically give attention to the following aspects:

i) The Categories of activities for CPD credits namely:

- Category 1: Development activities

- Category 2: Work based activities

- Natural Scientific work

- Extension Scientific work

- Mentoring of candidate practitioners

- Category 3: Individual activities

The final credits within the three Categories will finally be approved by the SASAE and SACNASP (SACNASP, 2015).

ii) The role of SASAE as a Voluntary Association:

- Assist their members in identifying CPD activities which meet their needs;

- Present CPD activities as described in Category 1; and

- Validation and monitoring courses, seminars and conferences for CPD credits by other providers.

iii) SASAE will be responsible for issuing specific certificates indicating the level of professional registration in the Science of Extension. It is however a prerequisite that the applicant must be a member of SASAE.

iv) SASAE need to investigate to register as a training provider, presenting skills programs in the Science of Extension to members and non-members. 
S. Afr. J. Agric. Ext.

Vol. 44, No. 2, 2016: $231-247$

DOI: http://dx.doi.org/10.17159/2413-3221/2016/v44n2a428
Davis \&

Terblanché.

(Copyright)

v) SASAE will be responsible to issue certificates of attending the conference, presenting a scientific paper/ popular paper/and or a poster, and a certificate to the presenter of the best scientific paper.

vi) SASAE need to get AGM approval to change the current membership categories in the Constitution to be aligned with the professional categories as indicated in Table 4.

\section{SUMMARY AND CONCLUSION}

This paper has summarised a review of literature on extension and advisory services in South Africa and internationally. Using the "best-fit" framework (Birner et al., 2009), the authors examined the policy environment, governance structures, capacity and management, and extension approaches.

As discussed in the Nairobi conference (Pye-Smith, 2012), the most successful extension approaches achieve the following: empower farmers and communities; take into account local culture and tradition; and frequently target specific groups such as women and young people. The best approaches tend to be participatory and demand-led; in other words, they respond to the individual needs of farmers and communities

Knowledge sharing is critical to supporting social, economic and environmental development, and extension and advisory services are a vital knowledge-sharing institution. According to GFRAS (2012), there are five opportunities to mobilise the potential of extension and advisory services $(\mathrm{p} 2)$ :
i. $\quad$ Focusing on best-fit approaches;
ii. Embracing pluralism;
iii. Using participatory approaches;
iv. Developing capacity; and
v. Ensuring long-term institutional support.

We therefore give the following policy recommendations for national policy-makers and decision-makers in agricultural extension and advisory services and education:

i. Higher education institutions must ensure that the qualifications in agriculture and in extension are in line with the SACNASP registration requirements.

ii. Higher education institutions should consider a postgraduate degree in extension for those who already have a technical degree but require further competencies in extension.

iii. Higher education institutions must clearly indicate to students the level of professional registration of each qualification.

iv. Higher education institutions and other trainers should provide functional skills for all those working in the agriculture sector, not just extension.

v. Higher education institutions and other trainers should reskill existing workers with functional and technical competencies to meet the challenges in RSA today.

vi. Employers of agricultural extensionists and advisors should make sure that employees can register with SACNASP.

vii. Employers advertising a vacancy must clearly indicate on what level of professional registration with SACNASP the employee must be registered to be able to apply for the vacancy.

viii. Policy-makers and employers should enhance the attractiveness of the profession through adequate salaries, incentives and awards and other types of recognition. 
S. Afr. J. Agric. Ext.

Vol. 44, No. 2, 2016: $231-247$

Davis \&

DOI: http://dx.doi.org/10.17159/2413-3221/2016/v44n2a428

Terblanché.

(Copyright)

ix. Policy-makers and research institutes should promote a vibrant culture of research to attract funding, students and quality human resources to extension.

x. Higher education institutions and extension research must engage with industry through seminars, tracer studies, and needs assessments to ensure they are producing graduates with relevant competencies and relevant research results.

xi. The role of SASAE as a Voluntary Association:

- To undertake an in-depth study to determine what the extension landscape currently look like and what is needed for the next 10 years;

- To establish a CPD Committee that will continuously determine what is needed for extensionists to improve their skills and knowledge;

- To establish an Education and Learning Committee who needs to evaluate extension qualifications and skills programs that will ensure extensionists to improve their skills and knowledge.

\section{REFERENCES}

BIRNER, R., DAVIS, K., PENDER, J., NKONYA, E., ANANDAJAYASEKERAM, P., EKBOIR, J., MBABU, A., SPIELMAN, D. HORNA, D. \& BENIN, S. 2009. From Best Practice to Best Fit: A Framework for Analysing Agricultural Advisory Services Worldwide. Journal of Agricultural Extension and Education 15(4), 341-355.

CHRISTOPLOS, I., 2010. Mobilizing the potential of rural and agricultural extension. FAO, Rome, Italy.

DEPARTMENT OF AGRICULTURE, FORESTRY AND FISHERIES (DAFF), 2014. Draft National Extension and Advisory Service Policy.

DIRECTORATE EDUCATION AND TRAINING. 2005. National Agricultural Education and Training Strategy and Forum. Pretoria: Department of Agriculture.

DIRECTORATE EDUCATION AND TRAINING. 2007. Report on the profiling of the current government-employed extension and advisory service officers. Pretoria: Department of Agriculture, Forestry and Fisheries.

DAVIS, K. E. 2015. The new extensionist: Core competencies for individuals. GFRAS Brief \#3. Lindau, Switzerland: Global Forum for Rural Advisory Services (GFRAS).

DÜVEL, G. H. 2003. Towards an appropriate extension approach for South Africa. Executive Report, South African Institute for Agricultural Extension, University of Pretoria, Pretoria.

FANZO, J., MARSHALL, Q., DOBERMANN, D., WONG, J., MERCHAN, R. I., JABER, M. I., SOUZA, A., VERJEE, N. \& DAVIS, K. E. 2015. Integration of Nutrition into Extension and Advisory Services: A Synthesis of Experiences, Lessons, and Recommendations. Food and Nutrition Bulletin 2015, 36(2), 120-137. DOI: 10.1177/0379572115586783.

GFRAS (GLOBAL FORUM FOR RURAL ADVISORY SERVICES). 2012. Building knowledge systems in agriculture - five key areas for mobilising the potential of extension and advisory services. GFRAS, Lindau, Switzerland.

IDOWU, I. O. 2015. Agricultural Extension Policy: The Missing Link for Enabling Extension and Advisory Services for Sustainable Agricultural and Innovations. Paper for the Global Forum for Rural Advisory Services (GFRAS). Lindau, Switzerland: GFRAS.

NATIONAL PLANNING COMMISSION. 2012. National Development Plan. Our future make it work. Department of the Presidency, Republic of South Africa.

PYE-SMITH, C. 2012. Agricultural Extension - A time for Change - linking knowledge to policy and action for food and livelihoods. Technical Centre for Agricultural and Rural Cooperation, Wageningen, The Netherlands. 
S. Afr. J. Agric. Ext.

Vol. 44, No. 2, 2016: $231-247$

DOI: http://dx.doi.org/10.17159/2413-3221/2016/v44n2a428
Davis \&

Terblanché.

(Copyright)

QAMAR, M. K. 2005. Modernizing National Agricultural Extension systems: A practical guide for policy-makers of developing countries. FAO, Rome, Italy.

RIVERA, M, R., QAMAR, M. K. \& VAN CROWDER, L. 2001. Agricultural and rural extension worldwide - options for institutional reform in the developing countries. FAO, Rome, Italy.

RIVERA, M, R. \& QAMAR, M. K. 2003. A new extension vision for food security Challenges to face. FAO, Sustainable Development Department, Rome, Italy.

ROMERO, L. 2012. Rural extension as part of an innovation. RELASER - Latin American Network for Rural Extension Services, January 2012.

SOUTH AFRICAN COUNCIL FOR NATURAL SCIENTIFIC PROFESSIONS (SACNASP). 2015. http://www.sacnasp.org.za/.

SWANSON, B. E. 2008. Global Review of Good Agricultural Extension and Advisory Services. FAO, Research and Extension Division, Rome, Italy.

SULAIMAN, V. \& DAVIS, K. E. 2012. The "New Extensionist": Roles, Strategies, and Capacities to Strengthen Extension and Advisory Services. Global Forum for Rural Advisory Services, Lindau, Switzerland.

TERBLANCHÉ, S. E. 2008. Towards an improved agricultural extension service as a key role player in the settlement of new farmers in South Africa. S. Afr. J. Agric. Ext. 2008, Vol. 37, 58-84.

TERBLANCHÉ, S. E. \& KOCH, B. H. 2012. The feasibility of establishing a professional South African extension and advisory body. Report for the Department of Agriculture, Forestry and Fisheries, Pretoria, South Africa. 